Article

\title{
Converging Urban Agendas: Toward Healthy and Sustainable Communities
}

\author{
Mark Roseland ${ }^{*, \dagger}$ and Maria Spiliotopoulou ${ }^{\dagger}$ \\ Centre for Sustainable Community Development, School of Resource and Environmental Management, \\ Simon Fraser University, Burnaby, BC V5A 1S6, Canada; mariaspi@sfu.ca \\ * Correspondence: roseland@sfu.ca; Tel.: +1-778-782-4161; Fax: +1-778-782-4968 \\ + These authors contributed equally to this work.
}

Academic Editor: Jerry D. Marx

Received: 21 December 2015; Accepted: 27 June 2016; Published: 5 July 2016

\begin{abstract}
In light of recent developments such as the COP21 Paris climate agreement, the UN adoption of the Sustainable Development Goals for 2030, and the Habitat III Conference, there is increasing recognition of the role of human settlements as key components of both global challenges and global solutions. "Urban sustainability" under various names has matured over the last three decades not only in planning and related fields, but also in wider professional and popular discourse. In this paper we trace a historical overview of urban sustainability theory and practice, and explain why urban sustainability planning and development currently face limited and inconsistent application. We show that this lack of public uptake is due in part to monitoring, assessment, and decision-support frameworks and tools that do not engage citizens and their governments in a shared "strong sustainability" analysis and/or vision. We argue that urban sustainability today clearly needs to embrace equity, inclusion, and other social considerations; contribute to constructive societal mobilisation and compelling policy-making; advocate for development as a better alternative to growth; encourage the integration of human and environmental health interests; and encompass triple-bottom-line-inspired outcomes. Focusing on community capital productivity and regeneration may be the key to advancing healthy and sustainable communities.
\end{abstract}

Keywords: urban sustainability; sustainable community development; urban productivity; sustainability planning; sustainability frameworks

\section{Introduction}

A growing number of scholars are referring to the modern period as "the Anthropocene", the era when human development is unfolding at a pace that is detrimental for our host planet [1]. A multitude of signs clearly indicate that the Earth cannot sustain the ever-growing human population; these signs include climate change and increased frequency of extreme phenomena; persistent poverty and inaccessibility to basic provisions like clean water and sanitation; and degradation of ecosystem services and species extinction at an unprecedented rate [2].

The argument that there should be limits to growth was established decades ago in the seminal report submitted by Meadows et al. to the Club of Rome [3], and it is finally gaining momentum [4,5]. We no longer live in an "empty world", but rather in a "full" one [6], with significant implications and repercussions for current and future generations. Current generations now have both the knowledge and the responsibility to lead humanity toward a more sustainable future [2].

In some cases the situation may not be irreversible; however, we now have more understanding of where the planetary boundaries are and, although some suggested thresholds seem to have been exceeded (genetic diversity, climate change, nitrogen cycle, and land-system change) [7], we need to make concerted efforts to remain within these interconnected boundaries [8]. According to current 
knowledge the Holocene is the only state of the Earth that can support human societies as we know them; human activity however has been extending the Earth's boundaries to the point that the planet as a system may lose it resilience, i.e., it may not be able to sustain the increasing anthropogenic pressure [7].

In light of recent developments such as the COP21 climate agreement, UN adoption of the Sustainable Development Goals for 2030, and the Habitat III Conference, there is increasing recognition of the role of human settlements as key components of both global challenges and also global solutions. Urban sustainability or Sustainable Community Development (SCD) is a holistic approach that integrates social, environmental, and economic considerations into the processes and actions undertaken by communities on their path toward sustainability. It entails progress in all forms of community capital: natural, physical, economic, human, social, and cultural [9]. For this paper we use the terms SCD and urban sustainability interchangeably.

We present an overview of the theories that have influenced urban sustainability theory and practice over time (Sections 2 and 3), and suggest a convergence of urban sustainability agendas with strong potential to contribute to healthy and sustainable communities (Section 4).

\section{Historical and Conceptual Overview}

The term "sustainable development" (SD) has been criticised as ambiguous and open to contradictory interpretations [10]; in the literature, it is more often referred to as the process, the effort, and activities leading to the end goal of sustainability [11]. "Development" should not be confused with "growth"; while quantitative increases (e.g., in income, population, production, and size) are aptly described as "growth", qualitative changes (e.g., in health, knowledge, quality of life, walkability, and efficient resource use) are more accurately described as "development" [9]. Moreover, sustainable development should not be conceived of as a trade-off between the environment and the economy, since protecting ecosystems and developing sustainably need not mean job loss or economic downturn. It is about a new way of thinking about economic development over the long term: it is about "doing development differently" [9].

In a study of several definitions of sustainability, Berke and Conroy [12] identified four common characteristics: (1) "balance" in integrating environmental, economic, and social aspects; (2) the potential of a system to regenerate (recreate and strengthen itself); (3) the recognition that local systems are part of a global system; and (4) the dynamic and ever-evolving nature of SD. They went on to describe SD as "a dynamic process in which communities anticipate and accommodate the needs of current and future generations in ways that reproduce and balance local social, economic, and ecological systems, and link local actions to global concerns" [12].

In this section we follow the progression from the "big picture" of global sustainability and the UN Sustainable Development Goals to local sustainability and Goal 11 on inclusive, safe, resilient, and sustainable cities. We highlight the importance of local communities in dealing with global sustainability issues and trace the underpinnings of sustainable development theory and practice, as these form the conceptual background of sustainable community development.

\subsection{Global Developments}

The principal global sustainability challenges in the 21st century, i.e., ecological integrity, social equity and cohesion, and economic prosperity, need to be addressed in an integrated way $[9,13]$. At the time of the UN Conference on Environment and Development (Rio Earth Summit, 1992), we were witnessing the dawn of more mainstream public awareness about environmental issues, also evident in the adoption of the Agenda 21, a sustainable development action plan for the 21st century [9]. Then, the ingredients for change included awareness and some level of political engagement and environmental initiatives, but not the technical capacity, social understanding, and political will for meaningful, structural change [14]. By the time of the World Summit on Sustainable Development in 
2002 , there was an increasing sense of crisis, as knowledge about the state of environmental systems showed a continued negative trend and need for urgent action [14].

In April 1987, the United Nations World Commission on Environment and Development, chaired by Gro Harlem Brundtland of Norway, released its much-heralded report, "Our Common Future" [9]. The Brundtland Commission Report showed that the poorest fifth of the world's population had less than two percent of the world's economic product while the richest fifth had 75 percent; and that the 26 percent of the world's population living in developed countries consumed between 80 and 86 percent of non-renewable resources and 34 percent to 53 percent of food products [15]. The report emphasised the principle and imperative of sustainable development, which it defined as "meeting the needs of the present without compromising the ability of future generations to meet their own needs" [16].

The Millennium Development Goals (MDGs), unanimously adopted in September 2000 by the United Nations Member States marked a new era for sustainability at the global level [17]. The MDGs were composed of eight goals, 21 targets, and 60 indicators, and encouraged action by a broad range of stakeholders in developed and developing countries, so as to address the multi-dimensional issue of extreme poverty by 2015. Several of the goals have been achieved, with notable decreases in poverty, mortality, and disease rates in the developing world; however, the MDGs have been criticised as vague and potentially leading to further inequality in an urban context $[18,19]$.

By 2012, when the Rio+20 Earth Summit took place, we find ourselves facing an implementation issue, as communities develop sustainability plans without being able to mobilize citizens and apply a holistic approach to their actions [20]. At that Summit, the post-2015 UN Development Agenda was initiated and, in September 2015, 193 countries adopted the Sustainable Development Goals (SDGs) [21]: 17 goals and 169 concrete targets and indicators aiming to tackle poverty, climate change, and inequality in both developed and developing nations [17]. This agenda is grounded in a holistic view of sustainability and on the significance of the environmental dimension of sustainable development for all SDGs. The acknowledgement of the need for integrated action is also evident in the recent UNFCCC COP21 Paris Agreement to keep the global average temperature "well below $2{ }^{\circ} \mathrm{C}$ above pre-industrial levels and to pursue efforts to limit the temperature increase to $1.5^{\circ} \mathrm{C}$ above pre-industrial levels" [22].

\subsection{The Role of Human Settlements}

The increasing recognition of the role of human settlements as key components of both global challenges and global solutions follows naturally the exponential growth of urban population: from $30 \%$ of the global population in 1950 to $54 \%$ in 2014, and expected to reach $66 \%$ in 2050 [23], which would correspond to three times the total global population in 1900. The world's urban areas, occupying $3 \%-4 \%$ of the world's land surface, use $80 \%$ of its resources, and discharge most of the planet's solid, liquid, and gaseous waste [24]. At the same time they become increasing vulnerable to climate change risks and, subsequently, face serious health challenges which are in turn linked to extended healthcare, infrastructure, and other costs burdening the economy and the environment [25].

However, communities today "constitute the arena where action is concretized; [...] they are transformative; they [...] are hubs of peer-to-peer learning and knowledge sharing" [26,27]. As early as the Rio Earth Summit in 1992, ICLEI-Local Governments for Sustainability (ICLEI) catalysed the adoption of Local Agenda 21, an initiative promoting a larger role for local authorities in sustainability planning [28]. Twenty years later, the Rio+20 conference encouraged sustainability assessment at the local community level [9]. The current global discussion on local SD solutions, as well as the recent adoption of UN Sustainable Development Goal 11 for "inclusive, safe, resilient, and sustainable" human settlements, again demonstrate the significance of urban sustainability [29]. Local governments are the laboratories for successful, monitorable, and transferable sustainability policies and practices, and quite possibly our best chance to deal with the environmental impact of human activity $[17,30]$. 
As governments were beginning to perceive the magnitude and ramifications of rapid urbanisation, the first UN Conference on Human Settlements (Habitat I), was convened in 1976 in Vancouver, Canada [28]. With Habitat III taking place 40 years later in October 2016 in Ecuador, the emphasis is on sustainable urban and territorial development which requires "(1) integrated policy formulation and implementation; (2) transformative renewal strategies; (3) environment planning and management; (4) planning compact and connected cities and regions; and (5) inclusive and participatory planning" [31].

One of the paradoxes related to urban sustainability is directly linked to the plethora of definitions for sustainable development and the various notions attached to it by researchers and practitioners. We want to highlight though that, despite the lack of definitional consensus, SCD, like SD, has three core elements on which researchers and practitioners generally agree: the environment (carrying capacity of the biosphere and resource management), the society (addressing equity, inclusion, cohesion, and poverty), and the economy (qualitative and quantitative economic performance) [9].

\subsection{Theories and Factors Influencing Sustainable Community Development over Time}

\subsubsection{Ecological Modernisation}

A key concept that has formed the basis of various environmental or development strategies as well as urban sustainability initiatives over the past two decades is ecological modernisation, which was coined in the 1980s as a response to the environmental degradation apparently due to the relentless pursuit of economic growth [28]. Through improvements in technology and design, energy and resource efficiency, and innovations in production, ecological modernisation primarily seeks to achieve congruence between the economic and the ecological dimensions of sustainability [28].

The ecological modernisation proponents believe that innovation and technology can provide sound solutions to environmental problems created by human activity and at the same time contribute to further growth by turning to a "cleaner" economy that internalizes the environmental risks [32]. This theory, reconciling resource efficiency and business growth, has also been called "a profitable sustainability" [33] and inspired some Northern European countries to develop environmental policies for emissions abatement and eco-efficient production processes in the 1990s [28].

The main debate on ecological modernisation relates to its scope, which is restricted to ecological and economic concerns, thus not incorporating important issues such as social equality, population trends, and inter- and intra-generational equity [28]. Especially in its early steps, ecological modernisation theory was primarily connected to mainstream theories promoting economic growth, such as capitalism and industrialism, and therefore subscribed to weak sustainability principles (see discussion below) [34].

There is also a tendency evident in ecological modernisation to rely on technological advance as the "magic formula" to cure or reverse environmental problems [35]. The persistence of efficiency solutions and technological innovations demonstrates the lack of an integrative approach to current global and local issues that require deeper social change $[28,36]$.

\subsubsection{Weak vs. Strong Sustainability}

In economics, sustainability is defined in terms of economic growth through the neoclassical production function, a widely used way to calculate economic growth: $Q=Q(K, L)$, where $Q$ is the quantity of economic output, $\mathrm{K}$ is capital (composed of human/manufactured capital or Kh and natural capital or $\mathrm{Kn}$ ), and L is labour. For neoclassical economists, production inputs (K and L) are substitutable. This however is not always the case: a sawmill (manufactured capital) and a forest (natural capital) are not necessarily substitutable, and some natural capital degradation or extinction is unquestionably irreversible [37].

Weak sustainability advocates assume that natural resources are super-abundant or that the elasticity of substitution between $\mathrm{Kn}$ and $\mathrm{Kh}$ is larger than 1 or that technological progress can 
increase the productivity of $\mathrm{Kn}$ at a faster pace than that of its depletion. They believe in perfect substitution between manufactured and natural capital of equal value, while the total capital stock remains constant $[38,39]$. Proponents of "weak sustainability" promote an anthropocentric worldview, that humans should dominate over nature and that economic growth (or human welfare) can continue indefinitely [34].

Moving gradually to stronger sustainability has been a subject in SD discussions for the past few decades, as ecological economists such as Herman Daly have argued that natural resources are not substitutable inputs since they are not infinite [6]. Strong sustainability holds that the various production inputs should exist independently $[40,41]$ and that in some cases environmental damage and resource depletion cannot be reversed [34]. For strong sustainability advocates, the existing stock of natural capital must be maintained (or even enhanced for the sake of future generations), because the functions it performs cannot be duplicated by manufactured capital. Therefore, ecological sustainability is a prerequisite to economic development (this viewpoint prefers the term "development" over the term "growth", as "development" additionally incorporates social equity and qualitative improvement) [42].

A middle perspective considers only "critical natural capital" (i.e., ecosystem services providing life-support functions) as non-substitutable [43]; it may thus be possible to substitute between forms of Kn that are not "critical" (e.g., raw materials, waste assimilation, and amenities) or when there is a significant benefit from resource depletion or a large cost for conservation [37]. This however assumes complete information about all natural capital and its depletion impact, which is not the case.

Questions that constitute arenas for debate and research in this area relate to how each type of capital can be accurately measured (particularly how to assign monetary values to ecosystem services), whether GDP is a good measure of progress toward sustainability, what measures and indicators can effectively account for resource degradation, social equity, and non-market services, etc. Summing up, strong sustainability seems to be heading in the right direction for SCD: preserving adequate amounts of all natural assets (not constant, because population and other factors change as well) while avoiding terminal damage to critical natural assets, and consciously seeking to address key social issues [9].

\subsubsection{Social Economy, Community Economic Development, Green Economy, and Self-Reliance}

The social economy discourse emerged as a community response to negative impacts of social and economic restructuring, for instance through free trade agreements and privatisation [44]. Although a number of definitions exist resulting in significant debates, SE generally refers to activities by democratically controlled organisations and associations that integrate a social and economic mission, exist between the private and public sectors, and/or use the market to pursue explicit social objectives $[44,45]$.

The social economy field has evolved rapidly, from simple forms of economic activity reflecting social or cultural values to social and green enterprise ventures. It is estimated that the social economy employs at least 2 million people in Canada and 11 million in the European Union [45]. Some SE initiatives have been criticised for operating inside the capitalist system and therefore by this system's rules instead of trying to change them [14].

Community Economic Development (CED), often considered as a predecessor of the social economy, refers to bottom-up initiatives and participatory processes in which economic activities that meet social needs and environmental well-being are developed [44,45]. Social economy and CED are not completely synonymous; CED is locally focused and emphasizes collective bottom-up action, whereas SE is not necessarily geographically focused and builds on both collective action and individual entrepreneurship [45]. Although social economy and CED mostly combine social and economic aspects of sustainability, they can considerably contribute to local sustainability when converged with SCD, which integrates the environmental dimension along with the other two [44].

Two more concepts are worth briefly mentioning here, as they relate to the social economy and CED discussion: green economy and self-reliance or eco-localism. The Rio+20 process popularised the "green economy", which brings environmental considerations into the social economy and uses 
the latter to advance equity concerns within sustainability. Related to the debate on weak and strong sustainability, this approach moves along a spectrum between initiatives that are criticised for not addressing societal transformation and those that prioritize equity and social needs over profit maximisation. According to Connelly et al. [14], "a critical point of differentiation is whether social economy/enterprise activities are able to generate their own capital, rather than relying on an ongoing subsidy from the derivatives of the mainstream economy and the politics of redistribution".

Eco-localism integrates social, economic, and environmental sustainability, by focusing on the creation of self-reliant economies at the local level [46]. Through self-reliance initiatives, diversification of local economies is encouraged so that communities meet their needs, foster equity and inclusion, manage energy and waste more efficiently, and become more aware of the environmental and social impacts of economic activities [9]. This approach recognizes that there may be limits to the natural and human capital within and around a given local community, and that the road to self-reliance requires collective agreement, capacity building, and decision-making based on the integrated concept of sustainable community development [46].

\subsubsection{Resource Efficiency, Circular Economy, and Urban Metabolism}

A further shift in sustainability thinking occurred with key research papers such as that by von Weizsäcker et al. [46], which states that an $80 \%$ increase in resource productivity could be achieved through the use of efficient design, technology, and management. Concepts like eco-efficiency, circular economy, and turning waste into resources have resulted in "green" economic and business strategies, called "resource efficient"; businesses have started to adopt such concepts and to use efficient design, technology, and management [47].

Meanwhile, the concepts of urban metabolism and circular economy build upon the perception of a city as an ecosystem in which energy and material are the inputs and wastes are the outputs [48]. Urban metabolism based on a circular economy has been propagated mostly by McKinsey and Company [49] and the World Future Council [24,50]. Studies using urban metabolism principles and metrics have shown the ever-increasing urban demand for natural resources [51] and this finding has formed the rationale for various sustainability and resource efficiency initiatives worldwide [52]. Overall, the above demonstrate an advancement in the environmental-economic dimension of sustainability, by moving from the effort to reduce the global impact of human activity on the environment to the potential of resource efficiency and regeneration, and self-reliance [53].

\subsubsection{The "Social" and "Just" Aspects of Sustainability}

Despite the existence of various definitions and interpretations of SD and SCD, in most cases the triple bottom line is prominent. From municipal sustainability plans to corporate sustainability reporting, they usually review the environmental, economic, and social dimensions of an activity or initiative. However, they are rarely reviewed with equal attention; the environmental and economic aspects of sustainability are generally more visible than the social aspect.

Social capital can encompass characteristics such as social responsibility, trust, shared knowledge, and norms (cognitive social capital), as well as networks, structures, and relations within and beyond a community (bonding and bridging social capital) [9,37]. It is potentially a public good, usually under-provided by private agents, and exists only when combined with trust, credibility, and reciprocity. In contrast with natural capital, social capital will not be depleted if it is increasingly being used, but will deplete very quickly if it is not used.

Some researchers consider that sustainability is an advancement of the environmental justice movement which emerged in the 1980s through the convergence of social and environmental activism [54,55]. The concept of environmental justice, which could be loosely defined as the right to clean and safe environment for all (or even the fair distribution of the social, cultural, and health impacts of environmental degradation), is critical for the achievement of SD and SCD goals. 
Agyeman, Bullard, \& Evans [54] explain that the relationship between environmental degradation and social capital, as described above, has three main characteristics: (1) the two aspects are progressing in parallel, in that-at any jurisdictional or geographical level—"human inequality is bad for environmental quality"; (2) environmental problems are incommensurately afflicting the poorest societal groups; and (3) both aspects need to be treated as parts of the holistic approach which constitutes the basis of sustainable development.

As Agyeman indicates [56], even though environmental sustainability is fundamental, the aspects of social equity and welfare have to be integrated with the environmental and economic aspects. He calls this connection "environmental quality-human equality" for present and future generations. Social sustainability then became stronger as researchers (e.g., [56,57]) and citizen movements demanded the inclusion of social concerns, such as intra-generational equity, into any SD discussion. The social dimension of SD has thus been introduced in the literature through concepts such as "environmental justice" [54], "just sustainability" [56] and "shared ethical framework" [58].

\subsubsection{Resilience}

Although an old concept for engineering, psychology, and disaster management, resilience with regards to ecological and socio-ecological systems was first introduced by the renowned natural scientist C.S. Holling in 1973. A resilient system is characterised by its dynamic nature, multiple stable states, uncertainty, and persistence to exist-even if altered —in face of gradual or rapid change $[9,47]$. An inclusive definition for resilience is "the capacity of a system to absorb disturbance and reorganize while undergoing change so as to still retain essentially the same function, structure, identity, and feedbacks" [59].

Both in the literature and in practice, sustainability and resilience seem to overlap in that they share some principles and goals. The theme of resilience in the context of cities has proven to be very popular in urban planning. Although there are a variety of definitions for and understandings of resilience in social sciences [60], Meerow et al. (2016) concluded that urban resilience has not been comprehensively defined yet, as such a venture requires that resilience thinking takes into account the complexity and dynamics of urban systems. They go on to define urban resilience as "the ability of an urban system - and all its constituent socio-ecological and socio-technical networks across temporal and spatial scales- to maintain or rapidly return to desired functions in the face of a disturbance, to adapt to change, and to quickly transform systems that limit current or future adaptive capacity" [61].

There is also another aspect of resilience that "concerns the capacity for renewal, re-organisation and development, which has been less in focus but is essential for the sustainability discourse...in a resilient social-ecological system, disturbance has the potential to create opportunity for doing new things, for innovation and for development" [62]. Even though adopting strategies for resilience is only a part of SCD policy-making, a city may be resilient not only with regards to a natural disaster, but also when facing economic or social turbulence. It is in this respect that resilience supports the normative nature of sustainability by recognizing that a sustainable society is one that is actively seeking to become a better society [9].

Resilience in urban planning is a key driving principle behind the "Transition Town initiative" that emerged in 2006 in the United Kingdom, in response to rising concerns about climate change and peak oil [63]. By emphasizing the need for local action, the "Transition Towns" movement encourages communities to take steps to reduce carbon emissions, prepare for an economy post-peak oil, and ultimately transition to more sustainable socio-technical systems [9]. Towns across the United Kingdom, Australia, the United States, and many more countries are using this framework to plan for sustainability; as of December 2015, there were 479 transition initiatives underway [64].

\subsubsection{The Ecological Footprint}

A great influencer of the sustainability assessment literature is the ecological footprint developed by Wackernagel and Rees, which estimates the land area and related natural capital required by 
any human activity, i.e., the land occupied by buildings or infrastructure and the land needed to produce food and production inputs and to assimilate pollutants [65]. The ecological footprint can offer a meaningful single measure of all global ecological impacts of human activities, at household, municipal, national or global levels. The degree to which the footprint of human activities exceeds the total productive area is a measure of unsustainability [9].

The ecological footprint tool compares human demand for resources to the renewable resources available for consumption, i.e., to the Earth's biocapacity. It estimates the global hectares (gha) necessary for human demand by adding up all of the area required to provide these renewable resources, the area of built infrastructure, and the area needed to absorb waste [66]. In 2011, the Earth's biocapacity was estimated at approximately 12 billion hectares which, if divided by the total population that year ( 7 billion), gives 1.72 gha per capita [67]. Advanced technology has expanded the Earth's biocapacity by approximately $13 \%$ in the last 50 years, but during the same time the global population increased by around 130\%, thus reducing the available biocapacity and raising the ecological footprint per person [68]. With the global human population projected to reach 9.6 billion by 2050 and almost 11 billion by 2100 [69], the amount of biocapacity available per capita will further decline.

In the 1970s, humanity entered a state known as "ecological overshoot" [67]: our annual demand for ecological resources has ever since been greater than what the planet can regenerate in a given year. When our consumption exceeds the ecosystem limits, we are drawing down our natural capital and entering a state of overshoot; in ecological footprint terms, we are then appropriating carrying capacity from "distant elsewheres" [65]. Earth Overshoot Day, calculated by Global Footprint Network, an international think tank focused on helping the human economy operate within Earth's ecological limits, is determined for a given year according to the number of days of that year that Earth's biocapacity suffices to provide for humanity's Ecological Footprint; the remainder of the year corresponds to the global overshoot [68].

While ecological footprints have commonly been used on a country scale, they can also be calculated and applied on a local scale. Human communities demand a high input of resources: the more populous the city and the richer its inhabitants, the larger its ecological footprint is likely to be. Although some developed world communities may appear to be sustainable, analysis of their ecological footprint shows that they appropriate carrying capacity not only from their own rural and resource regions, but also from "distant elsewheres" [9]. Where there is availability of reliable local data, the ecological footprint of a community is based on the bottom-up "component" method which reflects the consumption patterns of the local population [51]. For instance, the City of Vancouver, Canada, used this method to assess options for achieving their Greenest City 2020 goals; the action plan includes a short-term goal to achieve a 33\% reduction in the City's ecological footprint by 2020 and a longer-term goal to achieve a 75\% reduction by 2050 [70]. A related analysis of Metro Vancouver calculated its total ecological footprint in 2006 as an area around 36 times larger than the metropolitan region itself, and thus showed how far the City of Vancouver still is from the "one-planet living" principle included in its Greenest City Action Plan [51].

The ecological footprint analysis has been widely accepted for its strong scientific foundations and for being directly relevant to everyday life and consumption patterns; it has also been criticised for conceptual and methodological weaknesses, as well as for policy-related ineffectiveness [66]. In any case, this approach confirms that we need to minimize consumption of essential natural capital [66]. The question is how to achieve this in the face of contemporary challenges while maintaining or improving quality of life.

\subsubsection{Incorporating Public Health Concerns}

Public health is another field that influences sustainability theory, planning, and implementation, as a sustainable community is also a healthy community, reflecting the health of its citizens. A century ago, municipalities were instrumental in improving public health by preventing the spread of disease, then viewed as the main challenge for local government. However, health is influenced by the physical 
and social environments in which we live and work as well as by interventions from the healthcare system [9].

Since the mid-1980s, municipal governments in Europe and North America have adopted a broader conception of public health. The World Health Organisation recognizes that a healthy community respects the principles of participation, partnership, empowerment, and equity, and promotes comprehensive strategies for a health-supportive environment, a good quality of life, and sustainable community development [71]. The fundamental conditions and resources (social determinants) for health are peace, adequate shelter, education, food, income, a stable ecosystem, sustainable resources, social justice, and equity. Thus, a healthy community not only provides adequate housing that is affordable, secure, and fosters a sense of pride and place-it goes beyond housing to improve citizen health, in an integrated, sustainability-inspired sense.

\section{Urban Sustainability Implementation and Assessment Hurdles}

\subsection{Urban Sustainability Planning and Implementation Gap}

In the past three decades, recognition of global and local problems, increase of available data, expertise, and technology, and acknowledgement of the need to take action have led to the development and adoption of numerous urban sustainability plans around the world [20]. Similarly, an increase in the number of urban sustainability networks, during the same period, denotes the desire of local governments to cooperate, exchange knowledge and best practices, and be part of a global SD movement [72].

By signing the Aalborg Charter at the 1st European Conference of Sustainable Cities and Towns, organised by ICLEI in 1994 in the aftermath of the Rio Earth Summit, hundreds of local governments have committed to adopting and implementing Local Agenda 21 (LA21) in the form of their own sustainability action plans integrating participatory processes. LA21s promote multi-stakeholder engagement, ecosystem protection, sustainable urban planning, an holistic sustainability viewpoint, participatory decision-making, and establishment of a monitoring framework [28,73]. In 2002, ICLEI reported that more than 6400 communities around the world had committed to the Local Agenda 21 process by that time [74]; 10 years later, however, less than half of them had actively moved beyond the planning stage [20].

As ICLEI's researchers observe [20], municipalities around the world do not exclusively use the LA21 framework; their plans may be called "sustainable development plans", "sustainability action plans", "local sustainability strategies", "integrated development programmes", etc. For instance, around $25 \%$ of Canadian communities have adopted Sustainable Community Plans (SCPs) which encompass economic, ecological, and social goals [30], although not all have put implementation strategies in place due to several reasons: capacity-expertise deficit, inability to comprehend and work with the interdisciplinary nature of sustainability, funding shortage, lack of political will, external circumstances, etc. [75]. This gap between planning and implementation has not been without consequences; lost opportunities to act on sustainability, lack of credibility, and increased public scepticism $[9,30]$.

\subsection{Issues in Assessing Healthy and Sustainable Communities}

The assessment of plans for healthy and sustainable communities is considered an effective tool that follows implementation in order to gauge their success and measure performance in ecological, social, and economic terms [9]. Successful monitoring and assessment of healthy and sustainable communities entails tackling issues such as stakeholder engagement, place-specific challenges, and agreeing on shared theoretical grounds and practical vision [9]. Bond, Morrison-Saunders, and Howitt [76] identified the main debates currently influencing sustainability assessment: (1) the variety of definitions and interpretations of SD by stakeholders; (2) the importance of context for policy actors to agree upon the meaning, implementation, and assessment of SCD in their own case; (3) the relevance 
of timescales on which SCD plans are built and of impacts that go beyond political boundaries; (4) the dilemma between a reductionist (few indicators covering a broad range of topics) or a holistic approach (many indicators for comprehensive understanding); and (5) the prioritisation of processes or outcomes or both.

Developing an SCD assessment framework needs to be led by a set of guiding principles such as these: livelihood sufficiency and opportunity, intragenerational and intergenerational equity, precaution and adaptation, and resource maintenance and efficiency [77]. Certainly there is not one set of indicators that is perfect for every policy or project, especially given the complex nature of systems and sub-systems in a city [78]. However at least some criteria need to be met so that indicators can be an effective decision-making tool: relevant and meaningful, measurable and feasible, sufficient, timely and consistent, scale appropriate, participatory, and systemic and flexible/modifying [76,78-80].

SCD assessment contains various challenges and debates, most of which have been described above. At the same time, urban sustainability frameworks constitute a rapidly growing arena worldwide, as a multitude of agendas emerged in the past two decades: cities that are "sustainable", "green", "liveable", "smart", "resilient", "eco", "low carbon", "ubiquitous", etc. [32]. The genesis and evolution of most of these agendas seems to have been influenced by the major underpinnings of SD/SCD, ecological modernisation, and the emerging concept of regenerative development or regenerative sustainability [32].

A study of the related literature [32] showed that "sustainable city" is the most frequently mentioned and centrally placed agenda, followed by terms such as "smart city", "digital city", "eco city" and "green city". Smart city and digital city reflect a weak sustainability approach, because the use of technology is prominent as the obvious way to increase productivity, well-being and wealth; whereas the green or eco-city have gained momentum partly because of the increased awareness of climate change challenges. Amidst this multitude of agendas, it is clear that "sustainable city" has longer history, stronger policy associations, and definitely broader scope, i.e., the triple bottom line notion of sustainability. Contrary to perceptions that are popular among decision-makers, this study indicates that these urban sustainability terms should not be used interchangeably, because, although intertwined, they are grounded on various_-not necessarily compatible_-theoretical premises [32].

Additionally, in the recent years, public health professionals and activists have developed and promoted a "healthy cities" agenda aiming to integrate health concerns in community planning and development. The objective is to reach improved health outcomes and reduced health care costs through enhanced urban design [49]. Health concerns have also been occasionally incorporated into other urban agendas such as eco-cities, low carbon cities, and resilient cities, for obvious reasons: efforts to reverse environmental degradation, maintain ecological integrity, or sustain a status quo in face of climate or other challenges impact human health directly or indirectly [9,32].

The Leverhulme International Research Network "Tomorrow's City Today: An International Comparison of Eco-City Frameworks" looked closely at the various existing frameworks developed to assess urban sustainability. In the Network's final report, 43 internationally visible and replicable frameworks are identified and studied; most frameworks (34) have been launched since 2008 and that, contrary to what would be expected, only eight of them have been designed and/or promoted by governmental organisations [81]. The analysis suggests that the vast majority of SCD assessment frameworks fall under one of three broad categories in terms of purpose and usability in decision-making: (1) performance assessment; (2) certification, accreditation or endorsement; and (3) acting as a "planning toolkit" [81].

Joss et al. [81] observe that the 43 frameworks studied by the Leverhulme Network range from focused and minimal to broad and comprehensive sets of indicators (reductionism versus holism) and this often relates to the wide variations noticed in defining and interpreting urban sustainability. The question of process versus outcomes is also tackled in this report, but in conjunction with another dilemma, that of standardisation versus contextualisation. Standardizing sustainability assessment offers advantages such as common language, however urban sustainability is context-specific by 
nature; keeping this last point in mind may be the key to developing comprehensive frameworks that honour decision-making and participatory process while achieving set sustainability goals. At the intersection of standardisation and contextualisation, it may be helpful to consider indicator frameworks as "boundary objects", i.e., tools that can help operationalize SD and SCD across different policy boundaries [82].

The contextual character of SCD is linked to other issues discussed in the sustainability assessment literature today: (1) the difficulty in deciding the scope of a framework due to questions of spatial and jurisdictional boundaries; (2) the complexity in developing or using replicable and comparable frameworks [81]; and (3) the concerns related to accessible, timely, and reliable data. Standardised, out-of-the-box frameworks are usually excessively data-driven and therefore not always scalable and relevant to particular places, since factors related to social values and visions, community development, and culture may disconnect data from reality [83].

The main finding to emerge from the current research on SCD performance assessment is that the field is not yet fully developed. While there are many frameworks in existence, their development appears to be taking place in a haphazard, siloed manner. Most of these frameworks-and the decision-making processes that result from them-fail to acknowledge the importance of several aspects of sustainability: the systemic nature of cities [33], the strong need for integration of human and environmental health interests [84], the "globalizing world" in which resources are produced and consumed in different regions [85], the need for emphasis on social inclusion, equity, constructive societal mobilisation, and security [48]. These concerns are now manifested in the Sustainable Development Goals as well as the demand for strong sustainability approaches and a common language between sustainability researchers and practitioners and among policy-makers themselves [86]. It is evident, then, that sustainability frameworks need to be enhanced and possibly aggregated [81,87] so as to promote healthy community capital management and regeneration.

\subsection{The Community Capital Framework}

The Community Capital framework [9] and the tools that have been developed to operationalize it constitute an inspiration for our research in exploring the advancement of SCD planning and assessment. We use the term "Community Capital" (Figure 1) to include natural, physical, economic, human, social, and cultural forms of capital.

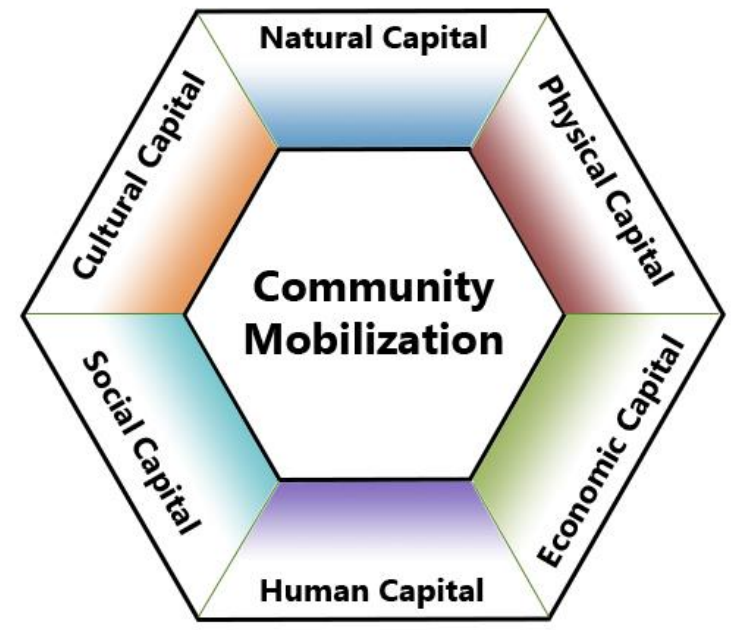

Figure 1. Community Capital: A Framework for Sustainable Community Development. Sustainable development requires mobilizing citizens and their governments to strengthen all forms of community capital. Community mobilisation is necessary to coordinate, balance and catalyze community capital. Source: [9]. 
(1) Natural Capital: Minimizing the consumption of essential natural capital means living within ecological limits, conserving and enhancing natural resources, using resources sustainably (soil, air, water, energy, and so on), using cleaner production methods, and minimizing waste (solid, liquid, air pollution, and so on).

(2) Physical Capital: Improving physical capital includes focusing on community assets such as public facilities (e.g., hospitals and schools), water and sanitation provision, efficient transport, safe and high-quality housing, adequate infrastructure, and telecommunications.

(3) Economic Capital: Strengthening economic capital means focusing on maximizing the use of existing resources (using waste as a resource, for example), circulating dollars within a community, making things locally to replace imports, creating a new product, trading fairly with others, and developing community financial institutions.

(4) Human Capital: Increasing human capital requires a focus on areas such as health, education, nutrition, literacy, and family and community cohesion, as well as on increased training and improved workplace dynamics to generate more productive and innovative workers; basic determinants of health such as peace and safety, food, shelter, education, income, and employment are necessary prerequisites.

(5) Social Capital: Multiplying social capital requires attention to effective and representative local governance, strong organisations, capacity-building, participatory planning, and access to information as well as collaboration and partnerships.

(6) Cultural Capital: Enhancing cultural capital implies attention to traditions and values, heritage and place, the arts, diversity, and social history [9].

The Community Capital Tool (CCT) is an SCD assessment tool built upon the Community Capital framework, and is the product of collaboration between the Centre for Sustainable Community Development at Simon Fraser University in Canada, with Telos, Brabant Center for Sustainable Development, Tilburg University, Netherlands. The six capital accounts of the CCT are broken down into a set of smaller stocks and requirements used to measure capital capacity and sustainability progress. The stocks are subsystems that influence the state and development of each capital account and can be considered as assets. These stocks are, for the most part, universal and were chosen based on their ability to accurately and efficiently represent the health of the capital they represent. Within each stock is a set of requirements that are chosen by the community to more closely represent the local needs and priorities of the community or of the specific initiative being measured. Lastly, each requirement is measured by one or more indicators. Indicators are specific, measurable entities (such as GHG emissions, unemployment rates, etc.) that "indicate" the status of each requirement. They are selected based on the ease (and cost) of their data collection, their correlation to the requirement being measured, and the reliability and integrity of their data sources. The CCT then rolls up the final results into a graphical reporting package that reports on the health of each capital account and each of their constituent stocks. Community leaders, planners, and citizens can use this information to compare the current sustainability status of their community with past results, and with other, comparable communities. The CCT was designed based on strong sustainability principles. It focuses on the issues specific to each individual community, but does so in a way that recognizes each community's regional and global impact on the environment and on society at large. The CCT is also designed to incorporate the democratic input of citizens in terms of values and priorities, and provides planners and decision-makers with a tool that helps them ensure that these values and priorities are reflected in their policy decisions [9].

Of course, the Community Capital Framework and Tool is only one of many frameworks and tools that have been developed to help plan for and assess sustainability; some present conceptual similarities [81] but most come from a variety of theoretical backgrounds [88], while almost all face practical challenges and limitations, as discussed in the previous section. Examples of other significant sustainability assessment frameworks include STAR Community Index, BREEAM Communities, One 
Planet Communities, the Foundation for Sustainable Area Development method, the Canadian Index of Wellbeing, and Vancouver Foundation Vital Signs.

\section{Converging Urban Agendas for Healthy and Sustainable Communities}

\subsection{Introduction}

As human settlements continue to grow and extract resources, they impose a "disproportionate" impact on the biosphere while suffering from economic and social issues within their boundaries [48]. We suggest that another transition, from a negative individualistic logic (reducing impact) to a positive systemic one (regeneration of resources) is imperative; a shift during which community, people, and environment not only coexist but are involved in a co-evolutionary process [89]. As explained above, the triple bottom line perception of sustainability has evolved over the last decades, resulting in a number of agendas which have not always involved a balanced approach between environmental, economic, and social concerns [32,53].

As SCD researchers and practitioners become more aware of planetary ecological constraints combined with urban population and economic growth, they increasingly recognise the significance of urban assets. Traditional economic growth, based on weak sustainability principles, urges cities to maintain or increase their economic output by improving technology, accumulating capital, and enhancing labour productivity. However, urban space that is planned using strong sustainability principles can lead to increases in human, resource, and process productivity, improved urban assets performance, ecological function regeneration and efficient use of resources $[49,90]$.

Urban areas may not be indefinitely sustainable if they continue to be extractive and not productive-it is the potential of advancing SCD through this concept of productivity that our current research explores. With this paper, we seek to advance the big picture-not necessarily by advocating for a new paradigm but by pointing toward a new direction that has the potential to offer a shared understanding. We introduce here our research on productive sustainability, an enhanced SD planning and assessment framework based on strong sustainability principles, aiming to operationalize SD that can successfully address issues of ecological integrity, social equity and cohesion, and economic prosperity.

\subsection{Urban Productivity and Regenerative Sustainability}

Neo-classical economics defines productivity as a function of labour and capital inputs. Theory has evolved to concepts such as Total Factor Productivity (TFP), which includes more types of input because a "significant" percentage of output could not be attributed to the neoclassical labour and capital inputs [35]. Around the 1980s and early 1990s, the TFP theory included the input of natural resources, policies, knowledge sharing, collaboration, and expertise, while in the 1990s it came to serve as the basis of local and regional economic development strategies, along with other concepts such as ecological modernisation, circular economy, cluster development, and innovation strategy [49]. These concepts and strategies resulted in the emergence of a wide range of urban development agendas as described above; agendas promoted by various actors and networks, oftentimes with the ambition to address social, environmental, and economic issues simultaneously, albeit usually without much success.

Drawing from these agendas, the limited regenerative or productive sustainability literature, and the realities of the 21st century, we argue that a productive city would seek to regenerate its resources, by being net-positive, i.e., producing more capital than it consumes [33,50,91]. What would a regenerative or productive city entail? Reduced ecological footprint, efficient renewable energy systems, regenerating soils with organic matter, replenishing plant nutrients, regenerating forests, restoring watersheds [24], regenerative water supplies, renewed human connection with nature, expanded green economy, increased livability, innovation, social inclusion, and participatory decision-making [86]. 
Productivity is multi-dimensional, in the same way as sustainability [92]; full productivity potential can only be achieved through a holistic approach, which integrates economic, social, and environmental factors and their myriad interconnections [93]. Enhancing productivity therefore entails investment and improvements at least in the following capitals: social (connectedness, tolerance, inclusion), human (knowledge, skills, health), physical (infrastructure, technology), and economic (financial and business resource allocation) [9,49].

The interdisciplinary nature of the productivity concept has the potential to offer the common language and the long-term and comparative perspective needed for SCD planning and assessment [86]. The increase of productivity at the local level requires the collaboration among all interested actors and can offer opportunities that have not been explored yet, for economic activities and new markets, employment and social inclusion, as well as preservation of the natural environment [52].

Productivity is a notion that resonates with people simply because it is relevant to everyday life; therefore it has potential for greater uptake than concepts such as sustainability that seem more abstract (particularly while researchers and practitioners still seek consensus on their definitions) [94]. Additionally, economic productivity is a quite developed concept in terms of theory and practice and it can be combined with functional definitions of social and environmental productivity in order to advance our understanding and implementation of sustainability.

The concept of productivity may also be seen as related to the perception of sustainability as a process; as Neuman and Churchill [95] explain, sustainability should be studied as applying in complex open systems and in life-cycle processes, since this is the way to go beyond "sustaining" the resources and reach "rates of production and regeneration that equal or exceed rates of consumption and by-product absorption". This perspective incorporates a dynamic approach to production and consumption which is present in the-new and modest-literature on urban productivity or regenerative sustainability $[48,91,96]$, as well as applying the laws of thermodynamics to urban systems which may have unclear boundaries. So, "what kind of city would we have if its assets, systems, and places were simultaneously competitive, livable, just, healthy, sustainable, smart, resilient, regenerative, safe, creative, and happy? In short..." a productive city [49].

Examples of small-scale productive or regenerative community initiatives can be found within municipalities such as Adelaide, Australia (efficient use of local resources, dynamic public consultations, major organic waste composting schemes, and impressive renewable energy development), and Copenhagen, Denmark (energy efficiency initiatives, public transit and cycling uptake, extensive information campaigns and debates, and exemplary waste management) [24]. Regenerative practices also exist around the world in the realm of sectoral policies such as energy (e.g., Beddington Zero Energy Development (BedZed) in the United Kingdom, Masdar in Abu Dhabi, Portland's Eco-District initiative, the Arbed scheme in Wales, United Kingdom, or districts in Frieburg and Hamburg, Germany), and agriculture (e.g., urban farming programmes in Havana, Cuba, community gardens in New York City and elsewhere, or energy efficient and hydroponic use of farmland in Shanghai and Beijing, China) $[9,24,97]$.

\subsection{Healthy and Productive Communities}

We need to move beyond initiatives that focus on only one or two dimensions of SD and work toward communities that explicitly integrate ecological, economic, and social sustainability principles and practices. We showed above that health is directly related to the holistic notion of sustainability - but how is health related to productivity?

Improving productivity in the workplace is not a new concept, but in the 20th century it was almost exclusively associated with economic growth, i.e., the increase of economic output and profit for a given organisation or economy [98]. This led industrialised countries, such as the United States, to "overwork" their labour force at the expense of their well-being, as manifested in recreational time, health, and activities strengthening social interactions [99]. 
Observing weak sustainability principles, technological innovation would replace human labour and enhance productivity, however history has showed that this has not been the case in some developed countries, where longer hours of work were required for growth despite post-World War II technological advances [100]. Seen, however, through a strong sustainability lens, the increase of labour productivity, which is often demanded today due to the pressure to lower labour cost, does not need to involve longer work hours or further technological innovation to replace human labour. More hours of work are not necessarily followed by proportional increases in productivity or prosperity as expressed by income [101].

In the modern economy, productivity should increase output through enhanced labour force [98] and healthier work and life conditions, while reducing the use of natural resources [102]. Improving work and life productivity that encompasses the principles of social equity and social inclusion has the potential to contribute to reversing the decline of social capital and contribute to healthier communities [37,99]. Investment in labour productivity, by creating opportunities for education, training, and employment for marginalised or less-favoured people, has beneficial effects on a community's health and mobilisation of social capital [37]. Investment in place-based productivity (in the workplace, in the community, at home, etc.) is associated with improved physical and mental health, higher performance, more robust personal relationships, continuous learning, and adaptation and sense of belonging $[49,103]$.

\section{Conclusions and Further Research}

We have shown above that the concept of sustainability has evolved from an effort to reduce the impact of human activity on the environment [37] to the potential of regeneration [36] and self-reliance [104], as viewed from a strong sustainability perspective [5,14]. Human settlements today generally extract resources at a rate faster than the biosphere can replenish; if this model continues, the natural ecosystem is at risk of collapse [85]. Since cities continue to grow while both reducing the biosphere's carrying capacity and suffering from economic and social issues, a shift in the sustainability paradigm is required. While a sustainable (net-zero) city focuses on limiting its ecological footprint and applying social considerations in the economy, a productive (net-positive) city would regenerate its resources by producing more than it consumes and by replenishing its capital from within.

The interdisciplinary nature of productivity has the potential to offer common language, shared understanding, and long-term perspective for SCD planning, implementation, and assessment. Current theoretical approaches and practical applications of environmental or economic productivity are not necessarily intertwined at the local level; in particular, most do not yet seem to adequately encompass social productivity. Local productivity requires multi-stakeholder collaboration and inclusion of social considerations, and thus can offer opportunities that have not before been fully explored.

Our current research involves the development of an analytical conceptual framework, drawing from a detailed literature review on urban productivity and regenerative sustainability. The focus then will center on testing the concepts and measures of economic, ecological, and social productivity in the urban context, through the application of the urban productivity framework on case studies in Canada. During this research we will utilize "Pando I Sustainable Communities", www.pando.sc, a web-based, multilingual, and fully-featured collaboration platform designed as a place for sustainability researchers and practitioners globally to meet, share ideas and work towards common SD and SCD goals [72]. Through the Pando network we will both disseminate our work and invite colleagues around the world to pilot our framework with communities in their own countries. By testing the urban productivity framework in as many communities as possible, we aim to improve its relevance, usability, and potential to provide much-needed integrated local solutions to global challenges. This research will aid in demonstrating whether a focus on converging these urban agendas, through a focus on community capital productivity and regeneration, may be the key to advancing healthy and sustainable communities. 
Acknowledgments: We appreciate Jeb Brugmann and the members of the Urban Productivity Collaborative (via Pando) for inspiring and encouraging our interest in urban productivity and regenerative sustainability.

Author Contributions: The authors contributed equally to this work. Both authors read and approved the final manuscript.

Conflicts of Interest: The authors declare no conflict of interest.

\section{References and Notes}

1. Hodson, Mike, and Simon Marvin. "Urbanism in the anthropocene: Ecological urbanism or premium ecological enclaves?" City 14 (2010): 298-313. [CrossRef]

2. Steffen, Will, Åsa Persson, Lisa Deutsch, Jan Zalasiewicz, Mark Williams, Katherine Richardson, Carole Crumley, Paul Crutzen, Carl Folke, Line Gordon, and et al. "The anthropocene: From global change to planetary stewardship." Ambio 40 (2011): 739-61. [CrossRef] [PubMed]

3. Meadows, Donella H., Dennis L. Meadows, Jorgen Randers, and William W. Behrens. The Limits to Growth. Washington: Club of Rome, 1972.

4. Meadows, Donella H., Dennis L. Meadows, and Jørgen Randers. Beyond the Limits: Global Collapse or a Sustainable Future. London: Earthscan Publications Ltd., 1992.

5. Hamstead, Meredith P., and Michael S. Quinn. "Sustainable Community Development and Ecological Economics: Theoretical Convergence and Practical Implications." Local Environment: The International Journal of Justice and Sustainability 10 (2005): 141-58. [CrossRef]

6. Daly, Herman E. “Economics in a Full World." Scientific American 293 (2005): 100-7. [CrossRef] [PubMed]

7. Steffen, Will, Katherine Richardson, Johan Rockström, Sarah E. Cornell, Ingo Fetzer, Elena M. Bennett, Reinette Biggs, Stephen R. Carpenter, Wim de Vries, Cynthia A. de Wit, and et al. "Planetary boundaries: Guiding human development on a changing planet." Science 347 (2015): 1259855. [CrossRef] [PubMed]

8. Rockström, Johan. "A safe operating space for humanity." Nature 461 (2009): 472-75. [CrossRef] [PubMed]

9. Roseland, Mark. Toward Sustainable Communities: Solutions for Citizens and Their Governments, 4th ed. Gabriola Island: New Society Publishers, 2012.

10. United Nations Department of Economic and Social Affairs. Sustainable Development Scenarios for Rio+20. A Component of the Sustainable Development in the 21st Century (SD21) Project. New York: United Nations Department of Economic and Social Affairs, 2013.

11. Sartori, Simone, Fernanda Latrônico, and Lucila Campos. "Sustainability and Sustainable Development: A Taxonomy in the Field of Literature." Ambiente \& Sociedade 17 (2014): 1-20. [CrossRef]

12. Berke, Philip R., and Maria Manta Conroy. "Are We Planning for Sustainable Development?" Journal of the American Planning Association 66 (2000): 21-33. [CrossRef]

13. International Council for Science (ICSU), and International Social Science Council (ISSC). Review of Targets for the Sustainable Development Goals: The Science Perspective. Paris: ICSU, 2015.

14. Connelly, Sean, Sean Markey, and Mark Roseland. “We Know Enough: Achieving Action Through the Convergence of Sustainable Community Development and the Social Economy." In The Economy of Green Cities. Dordrecht: Springer, 2013, pp. 191-203.

15. World Commission on Environment and Development. Report of the World Commission on Environment and Development: Our Common Future (The Brundtland Report). New York: WCED, 1987.

16. United Nations. "Report of the World Commission on Environment and Development-Our Common Future. Annex to Document A/42/427." 1987. Available online: http://www.un-documents.net/wced-ocf. htm (accessed on 2 October 2015).

17. Woolbridge, Michael. From MDGs to SDGs: What Are the Sustainable Development Goals? Bonn: ICLEI-Local Governments for Sustainability, 2015.

18. Harcourt, Wendy. “The Millennium Development Goals: A missed opportunity?" Development 48 (2005): 1-4. [CrossRef]

19. Meth, Paula. "Millennium development goals and urban informal settlements: Unintended consequences." International Development Planning Review 35 (2013): v-xiii. [CrossRef]

20. Rok, Ania, and Stefan Kuhn. Local Sustainability 2012: Taking Stock and Moving Forward_ICLEI Global Review. Bonn: ICLEI, 2012. 
21. United Nations. Resolution 70/1. Transforming our World: The 2030 Agenda for Sustainable Development. New York: United Nations, 2015.

22. United Nations. Adoption of the Paris Agreement (FCCC/CP/2015/L.9/Rev.1). Paris: United Nations, 2015.

23. United Nations Department of Economic and Social Affairs. World Urbanization Prospects: The 2014 Revision, Highlights (ST/ESA/SER.A/352). New York: UNDESA, 2014.

24. Girardet, Herbert. “Creating Regenerative Cities.” Available online: http://www.sustainable-performance. org/wp-content/uploads/2013/10/Regenerative-Cities.pdf (accessed on 12 September 2015).

25. Harlan, Sharon L., and Darren M. Ruddell. "Climate change and health in cities: Impacts of heat and air pollution and potential co-benefits from mitigation and adaptation." Current Opinion in Environmental Sustainability 3 (2011): 126-34. [CrossRef]

26. United Nations. The Future We Want (Resolution Adopted by the General Assembly on 27 July 2012) (A/RES/66/288). New York: United Nations, 2012.

27. UNDESA. World Economic and Social Survey 2013. New York: UNDESA, 2013.

28. Bayulken, Bogachan, and Donald Huisingh. "A literature review of historical trends and emerging theoretical approaches for developing sustainable cities (part 1)." Journal of Cleaner Production 109 (2015): 11-24. [CrossRef]

29. Kanie, Norichika, Naoya Abe, Masahiko Iguchi, Jue Yang, Ngeta Kabiri, Yuto Kitamura, Shunsuke Mangagi, Ikuho Miyazawa, Simon Olsen, Tomohiro Tasaki, and et al. "Integration and Diffusion in Sustainable Development Goals: Learning from the Past, Looking into the Future." Sustainability 6 (2014): 1761-75. [CrossRef]

30. Cairns, Stephanie, Amelia Clarke, Ying Zhou, and Vincent Thivierge. Sustainability Alignment Manual (SAM). Ottawa and Waterloo: Sustainable Prosperity and University of Waterloo, 2015.

31. UN HABITAT. International Guidelines on Urban and Territorial Planning: Towards a Compendium of Inspiring Practices. Nairobi: UN HABITAT, 2015.

32. De Jong, Martin, Simon Joss, Daan Schraven, Changjie Zhan, and Margot Weijnen. "Sustainable-smartresilient-low carbon-eco-knowledge cities; making sense of a multitude of concepts promoting sustainable urbanization." Journal of Cleaner Production 109 (2015): 25-38. [CrossRef]

33. Du Plessis, Chrisna. "Towards a regenerative paradigm for the built environment." Building Research $\mathcal{E}$ Information 40 (2012): 7-22. [CrossRef]

34. Williams, Colin C., and Andrew C. Millington. “The Diverse and Contested Meanings of Sustainable Development." The Geographical Journal 170 (2004): 99-104. [CrossRef]

35. Burkett, Paul. “Total Factor Productivity: An Ecological-Economic Critique.” Organization E Environment 19 (2006): 171-90. [CrossRef]

36. Reed, Bill. “Shifting from 'sustainability' to regeneration.” Building Research E Information 35 (2007): 674-80. [CrossRef]

37. Roseland, Mark. "Sustainable community development: Integrating environmental, economic, and social objectives." Progress in Planning 54 (2000): 73-132. [CrossRef]

38. Solow, Robert M. “An almost practical step toward sustainability." Resources Policy 19 (1993): 162-72. [CrossRef]

39. Ayres, Robert U. “On the practical limits to substitution." Ecological Economics 61 (2007): 115-28. [CrossRef]

40. Ayres, Robert U. "Eco-thermodynamics: Economics and the second law." Ecological Economics 26 (1998): 189-209. [CrossRef]

41. Ayres, Robert U. “Sustainability economics: Where do we stand?" Ecological Economics 67 (2008): 281-310. [CrossRef]

42. Bartelmus, Peter. "The future we want: Green growth or sustainable development?" Environmental Development 7 (2013): 165-70. [CrossRef]

43. Neumayer, Eric. "Human Development and Sustainability." Journal of Human Development and Capabilities 13 (2012): 1-19. [CrossRef]

44. Gismondi, Mike, Sean Connelly, Mary Beckie, and Mark Roseland. Scaling Up. Athabasca: Athabasca University Press, 2016.

45. Hernandez, Gretchen. "From Spaces of Marginalization to Places of Participation-Indigenous Articulations of the Social Economy in the Bolivian Highlands." Ph.D. Thesis, Simon Fraser University, Burnaby, BC, Canada, 14 May 2015. 
46. Von Weizsäcker, Ernst, Karlson Hargroves, Michael Smith, Cheryl Desha, and Peter Stasinopoulos. "Chapter 1-A Framework for Factor Five-The Natural Edge Project." In Factor 5: Transforming the Global Economy through 80\% Increase in Resource Productivity-A Report to the Club of Rome. London: Earthscan Publications Ltd., 2009.

47. Hodson, Mike, and Simon Marvin, eds. After Sustainable Cities? Abingdon, Oxon and New York: Routledge, 2014.

48. Newman, Peter, and Isabella Jennings. Cities as Sustainable Ecosystems: Principles and Practices. Washington: Island Press, 2008.

49. Brugmann, Jeb. “The Urban Productivity Imperative." In The Productive City: Growth in a No-Growth World (Pre-Publication Draft). Toronto: The Next Practice Ltd., 2015.

50. Girardet, Herbert. "Sustainability is Unhelpful: We Need to Think about Regeneration." Guardian, 10 June 2013. Available online: http:/ / www.theguardian.com/sustainable-business/blog/sustainabilityunhelpful-think-regeneration (accessed on 3 November 2015).

51. Moore, Jennie, Meidad Kissinger, and William E. Rees. “An urban metabolism and ecological footprint assessment of Metro Vancouver." Journal of Environmental Management 124 (2013): 51-61. [CrossRef] [PubMed]

52. OECD. OECD Green Growth Studies: Material Resources, Productivity and the Environment. Paris: OECD, 2015.

53. Brugmann, Jeb, and Eugene Mohareb. "The Productive City: Defining the practices of urban ecological development." Paper presented at the 8th World Congress of ICLEI-Local Governments for Sustainability, Belo Horizonte, Brazil, 14-17 June 2012.

54. Agyeman, Julian, Robert D. Bullard, and Bob Evans. "Exploring the Nexus: Bringing Together Sustainability, Environmental Justice and Equity." Space and Polity 6 (2002): 77-90. [CrossRef]

55. Salcido, Rachael E. "Reviving the Environmental Justice Agenda." Chicago-Kent Law Review 91 (2016): 115-37.

56. Agyeman, Julian. “Toward a 'just' sustainability?" Continuum: Journal of Media E Cultural Studies 22 (2008): 751-56. [CrossRef]

57. Agyeman, Julian. Introducting Just Sustainabilities: Policy, Planning, and Practice. London and New York: Zed Books, 2013.

58. The Earth Charter Initiative. The Earth Charter. Ciudad Colón: The Earth Charter Initiative, 2010.

59. Walker, Brian, Crawford S. Holling, Stephen R. Carpenter, and Ann Kinzig. "Resilience, Adaptability and Transformability in Social-Ecological Systems." Ecology and Society 9 (2004): 5.

60. Olsson, Lennart, Anne Jerneck, Henrik Thoren, Johannes Persson, and David O’Byrne. “Why resilience is unappealing to social science: Theoretical and empirical investigations of the scientific use of resilience." Science Advances 1 (2015): e1400217-1-11. [CrossRef] [PubMed]

61. Meerow, Sara, Joshua P. Newell, and Melissa Stults. “Defining urban resilience: A review." Landscape and Urban Planning 147 (2016): 38-49. [CrossRef]

62. Folke, Carl. "Resilience: The emergence of a perspective for social-ecological systems analyses." Global Environmental Change 16 (2006): 253-67. [CrossRef]

63. Baker, Susan, and Abid Mehmood. "Social innovation and the governance of sustainable places." Local Environment: The International Journal of Justice and Sustainability 20 (2013): 321-34. [CrossRef]

64. Transition Network. Available online: https://www.transitionnetwork.org/ (accessed on 3 November 2015).

65. Wackernagel, Mathis, and William E. Rees. Our Ecological Footprint. Gabriola Island: New Society Publishers, 1996.

66. Rees, William E. "Ecological footprints and biocapacity: Essential elements in sustainability assessment (Ch 9)." In Renewables-Based Technology: Sustainability Assessment. Edited by Jo Dewulf and Herman Van Langenhove. Chichester: John Wiley and Sons, 2006.

67. McLellan, Richard, Leena Iyengar, Barney Jeffries, and Natasja Oerlemans. WWF Living Planet Report 2014: Summary. Gland: World Wide Fund, 2014.

68. Ecological Footprint Network. Available online: http://www.footprintnetwork.org/en/index.php/GFN/ (accessed on 3 November 2015).

69. UNDESA. World Population Prospects: The 2015 Revision, Key Findings. New York: UNDESA, 2015.

70. City of Vancouver. "Greenest City 2020 Action Plan." 2012. Available online: http://vancouver.ca/files / cov/Greenest-city-action-plan.pdf (accessed on 3 November 2015).

71. World Health Organization. "WHO Healthy Settings Programme." Available online: http://www.who.int/ healthy_settings/en/ (accessed on 3 November 2015). 
72. Roseland, Mark, and Freya Kristensen. "Mobilising collaboration with Pando I Sustainable Communities." Local Environment: The International Journal of Justice and Sustainability 19 (2014): 469-78.

73. Clarke, Amelia. "Key structural features for collaborative strategy implementation: A study of sustainable development/local agenda 21 collaborations." Management \& Avenir 50 (2011): 153-71. [CrossRef]

74. ICLEI-Local Governments for Sustainability. "Second Local Agenda 21 Survey, Background paper No. 15." 2002. Available online: https://divinefreedomradio.files.wordpress.com/2013/10/ sustainabledevelopment2nd-prepsession.pdf (accessed on 3 November 2015).

75. Clarke, Amelia. Passing Go: Moving Beyond the Plan. Ottawa: FCM, 2012.

76. Bond, Alan James, Angus Morrison-Saunders, and Richard Howitt. Sustainability Assessment. Pluralism, Practice and Progress. Abingdon, Oxon and New York: Routledge, 2013.

77. Gibson, Bob, Selma Hassan, James Tansey, and Graham Whitelaw. Sustainability Assessment: Criteria and Processes. Abingdon, Oxon and New York: Routledge, 2005.

78. Meadows, Donella H. Indicators and Information Systems for Sustainable Development. Hartland: The Sustainability Institute, 1998.

79. UN SDSN. "Indicators and a Monitoring Framework for Sustainable Development Goals—Launching a Data Revolution for the SDGs." 2015. Available online: http://unsdsn.org/resources/publications/indicators/ (accessed on 12 September 2015).

80. Henderson, Nancy. "Measuring Up." The Social Planning and Research Council of BC News. 2006. Available online: http://www.sparc.bc.ca/resources-and-publications/doc/242-article-measuring-upsparc-bc-news-nancy-henderson-v23-no1-winter-2006.pdf (accessed on 15 November 2015).

81. Joss, Simon, Robert Cowley, Martin de Jong, Bernhard Müller, Boom Soon Park, W. Rees, Mark Roseland, and Yvonne Rydin. Tomorrow's City Today: Prospects for Standardising Sustainable Urban Development. London: University of Westminster, 2015.

82. Holden, Meg. "Sustainability indicator systems within urban governance: Usability analysis of sustainability indicator systems as boundary objects." Ecological Indicators 32 (2013): 89-96. [CrossRef]

83. Kitchin, Rob. "Making sense of smart cities: Addressing present shortcomings." Cambridge Journal of Regions, Economy and Society 8 (2015): 131-36. [CrossRef]

84. Secretariat of the Convention on Biological Diversity. Cities and Biodiversity Outlook: A Global Assessment of the Links between Urbanization, Biodiversity, and Ecosystem Services. Montreal: Secretariat of the Convention on Biological Diversity, 2012.

85. Kissinger, Mark, and William E. Rees. "Assessing Sustainability in a Globalizing World." Journal of Industrial Ecology 13 (2009): 357-60. [CrossRef]

86. Roseland, Mark. "Growth, Prosperity and Jobs for all, Within Planetary Boundaries (Final Issues Paper)." 2014. Available online: http://communitascoalition.org/pdf/Final_Urban_Prosperity_Roseland.pdf (accessed on 20 January 2014).

87. Joss, Simon, and Daniel Tomozeiu. "Eco-City" Frameworks-A Global Overview (Survey Conducted as Part of The Leverhulme International Network "Tomorrow's City Today). London: University of Westminster, 2013.

88. Tanguay, Georges A., Juste Rajaonson, Jean-François Lefebvre, and Paul Lanoie. "Measuring the sustainability of cities: An analysis of the use of local indicators." Ecological Indicators 10 (2010): 407-18. [CrossRef]

89. Neuman, Michael. "The Compact City Fallacy." Journal of Planning Education and Research 25 (2005): 11-26. [CrossRef]

90. Girardet, Herbert. Creating Regenerative Cities. Abingdon, Oxon and New York: Routledge, 2015.

91. Robinson, John, and Raymond J. Cole. "Theoretical underpinnings of regenerative sustainability." Building Research E Information 43 (2015): 133-43. [CrossRef]

92. World Confederation of Productivity Science. Available online: http://www.wcps.info/ (accessed on 10 November 2015).

93. Burgess, Thomas F., and John Heap. "Creating a sustainable national index for social, environmental and economic productivity." International Journal of Productivity and Performance Management 61 (2012): 334-58. [CrossRef]

94. Berke, Philip R. “Does Sustainable Development Offer a New Direction for Planning? Challenges for the Twenty-First Century." Journal of Planning Literature 17 (2002): 21-36. [CrossRef] 
95. Neuman, Michael, and Stuart W. Churchill. "A general process model of sustainability." Industrial $\mathcal{E}$ Engineering Chemistry Research 50 (2011): 8901-4. [CrossRef]

96. UBC. “UBC Centre for Interactive Research on Sustainability—Regenerative Neighbourhoods Program." Available online: http://cirs.ubc.ca/research/research-portfolio/regenerative-neighbourhoods (accessed on 29 August 2015).

97. Hunt, Miriam, and Carla De Laurentis. "Sustainable regeneration: A guiding vision towards low-carbon transition?" Local Environment: The International Journal of Justice and Sustainability 20 (2015): 1081-102. [CrossRef]

98. Jackson, Tim, and Peter Victor. "Productivity and work in the 'green economy'." Environmental Innovation and Societal Transitions 1 (2011): 101-8. [CrossRef]

99. Putnam, Robert D. “Bowling Alone: America's Declining Social Capital." Journal of Democracy 6 (1995): 65-78. [CrossRef]

100. Schor, Juliet B., and Dennis Chamot. "Workers of the world. Unwind." Technology Review 94 (1991): 24.

101. Knight, Kyle W., Eugene A. Rosa, and Juliet B. Schor. "Could working less reduce pressures on the environment? A cross-national panel analysis of OECD countries, 1970-2007." Global Environmental Change 23 (2013): 691-700. [CrossRef]

102. Davies, John. "The Ecological Footprint, Sustainability and Productivity." Management Services 52 (2008): $35-40$.

103. Jackson, Tim. Prosperity without Growth? - The Transition to a Sustainable Economy. London: Sustainable Development Commission, 2009.

104. Curtis, Fred. “Eco-localism and sustainability.” Ecological Economics 46 (2003): 83-102. [CrossRef]

(C) 2016 by the authors; licensee MDPI, Basel, Switzerland. This article is an open access article distributed under the terms and conditions of the Creative Commons Attribution (CC-BY) license (http:/ / creativecommons.org/licenses/by/4.0/). 